\title{
Reconstruction of Professional Teacher Education Program
}

\author{
Mangaratua M. Simanjorang* Abil Mansyur, Syawal Gultom \\ Faculty of Mathematics and Natural Sciences, Universitas Negeri Medan, Jl. Willem Iskandar Pasar V, Medan \\ Estate, Medan
}

\begin{abstract}
The Professional Teacher Education Program (in Indonesia known as Pendidikan Profesi Guru - PPG) was developed by the teacher training university by referring to Teacher Education Standards which include educational standards, research standards, and community service standards. Article 17 (1) of The Act Number 12 of year 2012 concerning Higher Education states that professional education is a higher education after an undergraduate program that prepares students for works, which need special expertise requirements. Based on this article of The Act, the competencies of PPG graduates that should include four professional teacher competencies, which are professional, pedagogical, personal and social competencies, should be more than undergraduate's competencies. However, do the material and evaluation systems currently show such a relationship? Besides that, the social, personal, professional and pedagogical abilities of the teacher are not abilities that are mastered separately but rather the overall integration of these abilities which shows the professionalism of the teacher. This article discusses the weaknesses of the current PPG program implementation and the efforts to reconstruct it to obtain a PPG program implementation system that takes into account the comprehensive and integrated competencies as learning outcomes of the program's graduates.
\end{abstract}

Keywords: professional teacher, Professional Teacher Education Program, professional education

DOI: $10.7176 / \mathrm{JEP} / 11-16-12$

Publication date:June 30th 2020

\section{Introduction}

The mandate of the article 8 of Indonesian Law Number 14 of 2005 concerning teachers and lecturers states that teachers must have academic qualifications, competencies, educator certificates, physically and mentally healthy, and have the ability to realize national education goals. Teacher preparation as a professional educator is also stated in Government Regulation Number 19 of 2017. These regulations underlie the occurrence of teacher reform in Indonesia where teachers must be prepared through professional education after the undergraduate program.

The Teacher Professional Education (in Indonesian Pendidikan Profesi guru-PPG) Program was developed by teacher training institution by referring to Teacher Education Standards which include education standards, research standards, and community service standards. Article 17 (1) of Law Number 12 of 2012 concerning Higher Education states that professional education is Higher Education after an undergraduate program that prepares students for work that requires special expertise requirements. Based on this article, PPG graduate competencies, which include four professional teacher competencies (professional, pedagogical, personal and social), should be more than that of undergraduate competencies.

Nurlaela (2018) states that PPG is the last line for Indonesia's education to get professional teachers. In other words, if the dream of a good quality Indonesian education is to be realized, PPG is a critical point for efforts to maintain the quality of teachers in the future. Thus, it is necessary to ensure the quality of the implementation of PPG so that the quality of its output which is the professional teacher can be guaranteed. But is the current practice of implementing PPG ideal in accordance with the demands of the legislation in force? Does the current PPG implementation system guarantee the quality of professional teachers produced? This question still needs to be considered even though PPG has been going on for a certain period and produced a number of certified teacher classes. Deep and critical reflection needs to be done to find opportunities for improvement that can be done to improve the quality of the implementation of the PPG program.

One important aspect that needs attention is the competence of PPG program graduates. So far it can be seen that the measurement of professional teacher competency is still partial in the sense that the four professional teacher competencies as regulated in the law are still viewed and measured separately. How the teacher's pedagogical abilities are related to his professional abilities has not yet been reflected. For example, let's say the approach used in learning should be adjusted to the topic being taught. However, do the material and evaluation systems currently show such a relationship? Professional teachers master the material in their scientific fields and can choose the right approach for each material that is adapted to the conditions of students and their learning environment and is able to build healthy social relationships with students and the educational environment as a whole person who is also a member of the educational environment. Teacher's social, personal, professional and pedagogical abilities are not abilities that are mastered separately but rather the overall integration of these abilities that shows the professionalism of the teacher. 
Besides that, because PPG is a tertiary education after an undergraduate program, it is appropriate that the competencies stipulated are more than those of graduates from undergraduate program. This will be related to teaching materials offered in the PPG program. So far in general the material offered in the PPG program is still a repetition of material obtained in the undergraduate program. So that a significant difference in competencies gained through the PPG program is still not clearly seen.

Considering this, the research team was called upon to reconstruct the current PPG program implementation system to obtain a PPG program implementation system that takes into account the competencies of graduates who are comprehensive and integrated. This research was trying to formulate what kind of revisions are needed to be considered in order to improve current PPG program.

\section{Teacher Professional Education}

Education is a valuable future investment. The government has committed that education for future generations must begin and be prepared earnestly. For this reason, the process of seeding the future generation must be accompanied by the preparation of professional teachers through a quality and accountable teacher education system.

The government's commitment to educate the Indonesian people is the mandate of the Preamble of the 1945 Constitution as written in the fourth paragraph stating that ".... Then thereafter to form an Indonesian Government that protects all Indonesian people and all of Indonesia's region and to promote public welfare, educate the life of the nation, ..... ". In addition, in Article 31 paragraph (3) of the amended 1945 Constitution, it is stated that the Government is endeavouring and implementing a national education system that enhances faith and piety and noble character in the context of educating the life of the nation, which is regulated by law.

The year 2005 was a milestone in the appreciation and protection of the teaching profession, because in this year the government launched Law Number 14 of 2005 about Teachers and Lecturers. In this law it is stated that the teacher is a profession. Article 1 (1) of this Law states that teachers are professional educators whose main tasks are educating, teaching, guiding, directing, training, evaluating, and evaluating students in early childhood education through formal education, basic education and secondary education.

The preparation of teachers as a profession is stated in Government Regulation Number 19 of 2017 about Amendments to Government Regulation Number 74 of 2008 concerning Teachers. Apart from that the teacher must be qualified from an undergraduate degree, the teacher must have a professional educators certificate which was obtained through professional education. Article 2 of the Indonesian Government Regulation Number 74 of 2008 states that teachers are required to have academic qualifications, competencies, educator certificates, physically and mentally healthy, and have the ability to realize national education goals. Furthermore Article 4 paragraph (1) Educator Certificate for teachers is obtained through professional education programs organized by universities that have an accredited education personnel procurement program, both organized by the Government and the Community, and determined by the Government. In paragraph (2) it is stated that the professional education program as referred to in paragraph (1) is only followed by students who already have an Academic Qualification from undergraduate program in accordance with statutory provisions.

To realize the mandate of the law in the context of preparing professional teachers, the government has prepared a Teacher Professional Education Program (PPG). The PPG program in Indonesia is in accordance with the mandate of the law. Article 17 (1) of the Higher Education Law states that professional education is Higher Education after an undergraduate program that prepares students for work that requires special expertise requirements.

Teacher Professional Education Program (PPG Program) as stated in Article 1 point 5 of the Minister of Research, Technology and Higher Education Regulation Number 55 Year 2017 concerning Teacher Education Standards is an education program that is held after an undergraduate or applied degree program to obtain an educator certificate on education early childhood formal education, basic education, and/or secondary education. There are two types of PPG Programs based on target groups, namely:

a. PPG for Pre-service teacher

PPG program that is intended for prospective teachers who have fulfilled the requirements for academic qualifications and will apply to become teachers.

b. PPG for in-service teacher

PPG program that is intended for teachers in-service. In-service teachers are teachers of civil servants and noncivil servant teachers who have taught at education units, whether held by the central government, regional governments, or community education providers who have work agreements or collective work agreements.

PPG Program is an educational program that is organized to prepare graduates of Educational and NonEducational Undergraduate program who have the talent and interest to become teachers so that they can master teacher competence in full in accordance with national education standards so that they can obtain certificates of professional educators in early childhood education, basic education and secondary education. The PPG Study Program is expected to answer various educational problems, such as: (1) shortage of teachers (shortage) 
especially in the outermost, frontier, and disadvantaged regions, (2) unbalanced distribution, (3) low level qualifications

\section{Method}

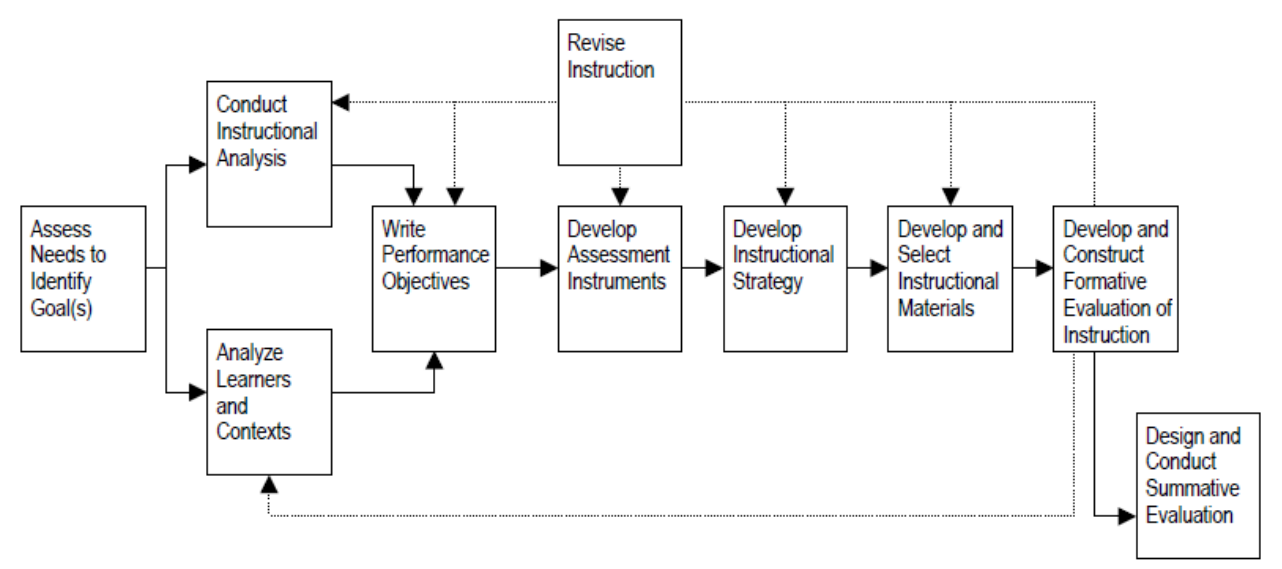

Figure 1. Dick \& Carey Model (2015)

The target of this research enters into the realm of educational research and development. Educational research and development is a development model in which research findings are used to design new products and procedures which are then systematically tested, evaluated and refined to meet a number of established criteria such as effectiveness, quality, or other equivalent standards (Borg \& Gall, 2003). This research and development has an important role in improving the quality of education because it involves a quasi-relationship between systematic program evaluation and program development. There are many development model schemes proposed by experts, one of which is a model designed by Dick and Carey (2015).

The Dick \& Carey model as presented in Figure 1 includes 10 stages. The first step is defining the objectives of the instructional program or product. This stage often requires a needs analysis. Steps 2 and 3 can be done in the opposite order or together. In step 2 instructional analysis is carried out to identify specific skills, learning procedures and tasks that are needed for goals to be achieved. Step 3 is designed to identify the ability and initial attitude of program participants, the characteristics of the program arrangements, and the characteristics of the settings in which new knowledge and abilities will be used. Step 4 translates the needs and objectives of the program into specific performance targets. This performance goal is a way of communicating the objectives of the program or instructional product at different levels with different types of stakeholders. These performance goals also provide the basis for designing test instruments, instructional materials, and instructional approaches that are needed. In step 5 an assessment instrument is developed. This instrument should be directly related to the knowledge and capabilities described in the performance objectives. In step 6 specific instructional strategies are set to help program participants achieve performance goals. Step 7 includes the development of instructional materials such as handbooks, media training guides needed and other materials that support the achievement of performance goals. Steps 8 to 10 of the Dick \& Carey model include differences in formative and summative evaluations formulated by Scriven (1967; Borg \& Gall, 2003). Formative evaluation (step 8) is carried out during the development process and the results of this evaluation are used in step 9 to revise any work that needs to be repaired that was carried out in the previous seven steps. Dick \& Carey recommends 3 stages of formative evaluation: one-on-one trials (an evaluator confronts a participant), small group trials (consisting of 6-8 students) and trials to large groups with conditions equivalent to groups that will use the results of development. The one-on-one trial phase is very dependent on qualitative methods such as interviews and observations (Dick \& Carey, 2015; Borg \& Gall, 2003). Input from this stage is used to revise certain parts of the seven previous steps that need to be corrected. Furthermore, after the revision was carried out a small group trial was carried out while still utilizing qualitative methods to obtain the revised input needed. After that the third test is conducted on large groups whose characteristics are equivalent to the characteristics of the users of the later development products. At this stage the evaluation tends to use quantitative methods to measure the extent to which the program has achieved its stated goals. After the development process is complete, then a summative evaluation is carried out (step 10). Dick \& Carey (2015) explained that in fact step 10 was not an integrated part of the development process and was carried out by an independent evaluator to test the feasibility of the development product obtained. 


\section{Discussion}

Based on the analysis of a number of available documents, it can be understood that professional education is higher education after the undergraduate program which prepares students to have jobs with special skills requirements (Ministerial Regulation number 87 of 2013, article 1). This definition clearly emphasizes that professional education is education after an undergraduate program thus the burden of material and targets of professional education programs should exceed the material burden and objectives of undergraduate programs. Based on this definition the Teacher Professional Education Program (PPG) is an educational program organized to prepare graduates of Education and Non-Education S1 / DIV Non-educational graduates who have the talent and interest to become teachers to fully master teacher competencies in accordance with national education standards so as to obtain a certificate of professional educators in early childhood education, basic education and secondary education.

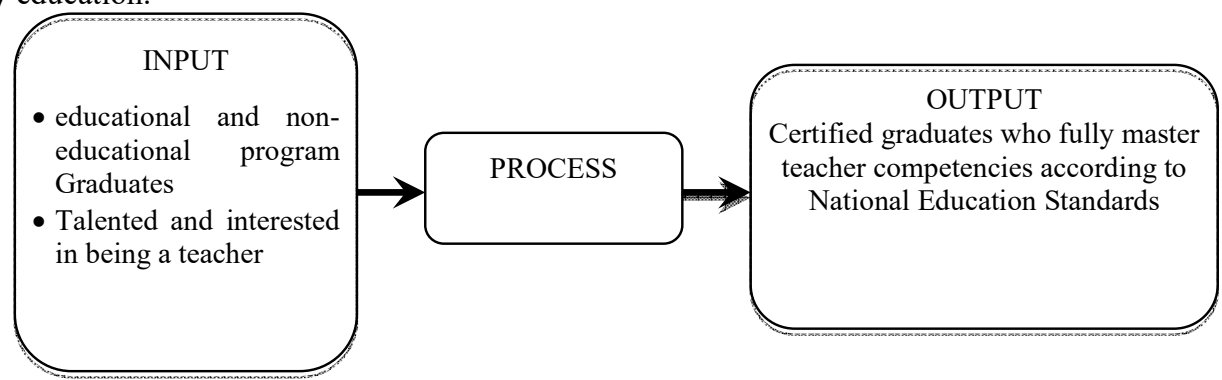

Figure 2. Input and Output of PPG Program

This definition emphasizes what are the inputs and outputs of the PPG program. Those who can take part in the PPG program are not limited to graduates of educational program but also open up opportunities for noneducational graduates. However, even though PPG program inputs are open, the PPG program output targets are graduates who have mastered teacher competence as a whole. Besides that, the definition above explicitly states that the program is held to prepare those who have the talent and interest to become teachers. In other words, in addition to having a graduate certificate, prospective PPG program participants must have the talent and interest to become teachers. While the Ministry of Research, Technology and Higher Educational Regulation number 55 of 2017 article 5 stipulates that the admission system for new students includes: selection of academic abilities and selection of talents, interests, personalities, and fitness. Based on these two rules, the selection of acceptance of prospective PPG program participants should include academic abilities, talents, interests, personalities and fitness. Thus a method will be needed that can reveal the talents and interests of participants to become teachers. Ways that can be used for this purpose can be in the form of tests, interviews or questionnaires. So far the test used to select prospective PPG program participants is the Teacher Competency Test. However, the intended test needs to be reviewed in terms of its ability to reveal the talents and interests and personality of prospective program participants. Competency tests tend to reveal the actual academic abilities of test takers and are often unable to reveal the potential abilities of test takers that are included in the potential talents of the test participants. For this reason, if a similar test will be used as a selection instrument for prospective program participants, it must be ensured that the instrument has the ability to reveal the actual and potential abilities of the test takers. In addition, instruments for measuring the interests and personality of the selection participants need to be added in the selection process of prospective PPG Program participants. Teachers are the spearhead of the formation of individual future generations of the nation. For this reason a teacher's personality must be considered because it will greatly affect the formation of student personality later. Thus prospective participants must have personalities that are in accordance with the teaching profession. After personality assessment, it is followed by tests of interests and talents and academic competence.

Furthermore, the Ministry of Education and Culture Regulation number 87 of 2013 stipulates matriculation which in this case is defined as a number of courses that must be attended by PPG program participants who have been declared to have passed the selection to meet academic competencies in the field of study and / or academic competencies before joining the PPG program. However, this matriculation is limited to noneducational and educational graduates who take a cognate course. While taking into account the policy of decentralization of education that allows variations in the competence of tertiary education graduates, this matriculation policy needs to be expanded for prospective participants who are still considered to need additional studies in certain fields. This is considered necessary especially for in-service teachers. In other words the results of the academic competency test will be used as a consideration for the matriculation course that will be followed by participants before joining the PPG program. 


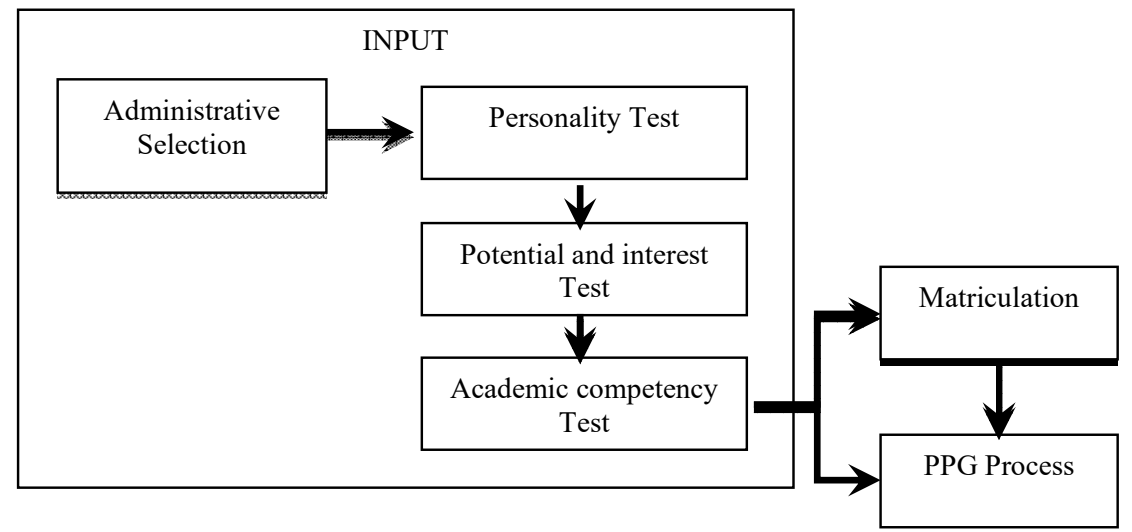

Figure 3. Selection phases for PPG Program Input

Furthermore the Ministry of Research, Technology and Higher Educational Regulation number 55 of 2017 Article 17 describes the education standards of the PPG program which include: graduate competencies, content, processes, assessments, educators and staff, facilities and infrastructure, management and funding. Graduates' competency standards, content and processes in the implementation of PPG programs cover the four professional teacher competencies, namely: pedagogical, personal, professional and social competencies, which are equivalent to the $7^{\text {th }}$ level of qualifications at the Indonesian National Qualification Framework. In other words PPG program graduates must have the ability to: (i) plan and manage resources as well as evaluate comprehensively, (ii) solve problems, (iii) conduct research and make strategic decisions related to their scientific fields through a mono-disciplinary approach. Thus the process of implementing the PPG program must guarantee the development of the four competencies of professional teachers so that they meet the qualifications of this $7^{\text {th }}$ level. Furthermore, the assessment in this program should also be able to measure the fulfilment of the qualifications of the $7^{\text {th }}$ level.

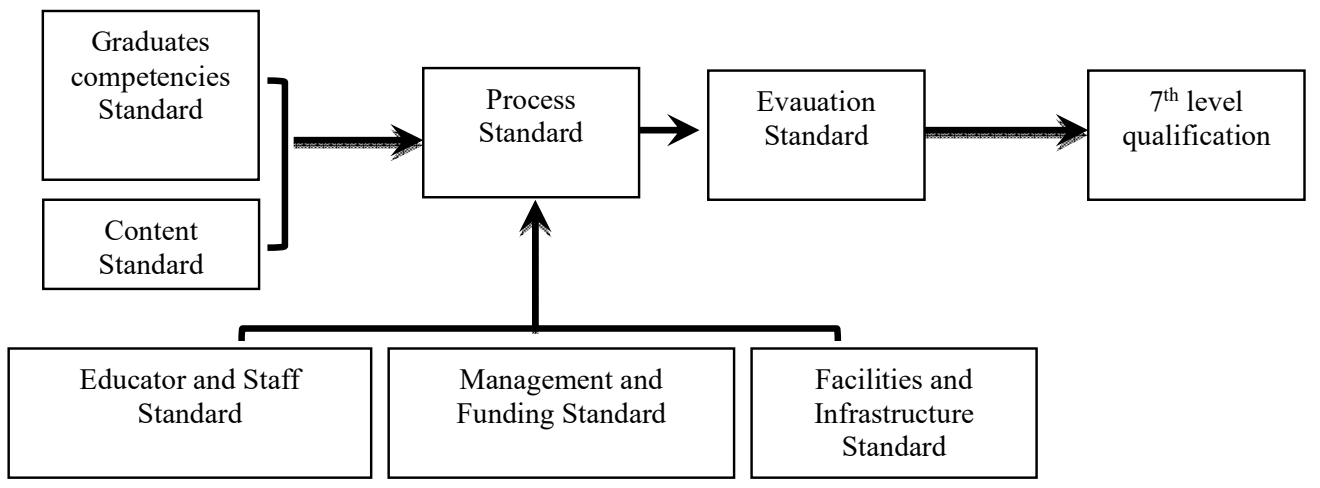

Figure 4. PPG Program Standard

The curriculum structure of the PPG program consists of workshops developing learning tools, teaching experience through micro learning, learning with peers, and the apprenticeship Program, and enrichment programs for study and/or pedagogy. Workshops for developing learning tools and field experience programs were conducted with intensive direct monitoring by supervisors and tutors assigned specifically for these activities. The workshop on the development of learning tools and field experience programs was carried out with the orientation on achieving competence in planning and implementing the learning process, assessing learning outcomes, following up on assessment results, as well as conducting mentoring and training. 


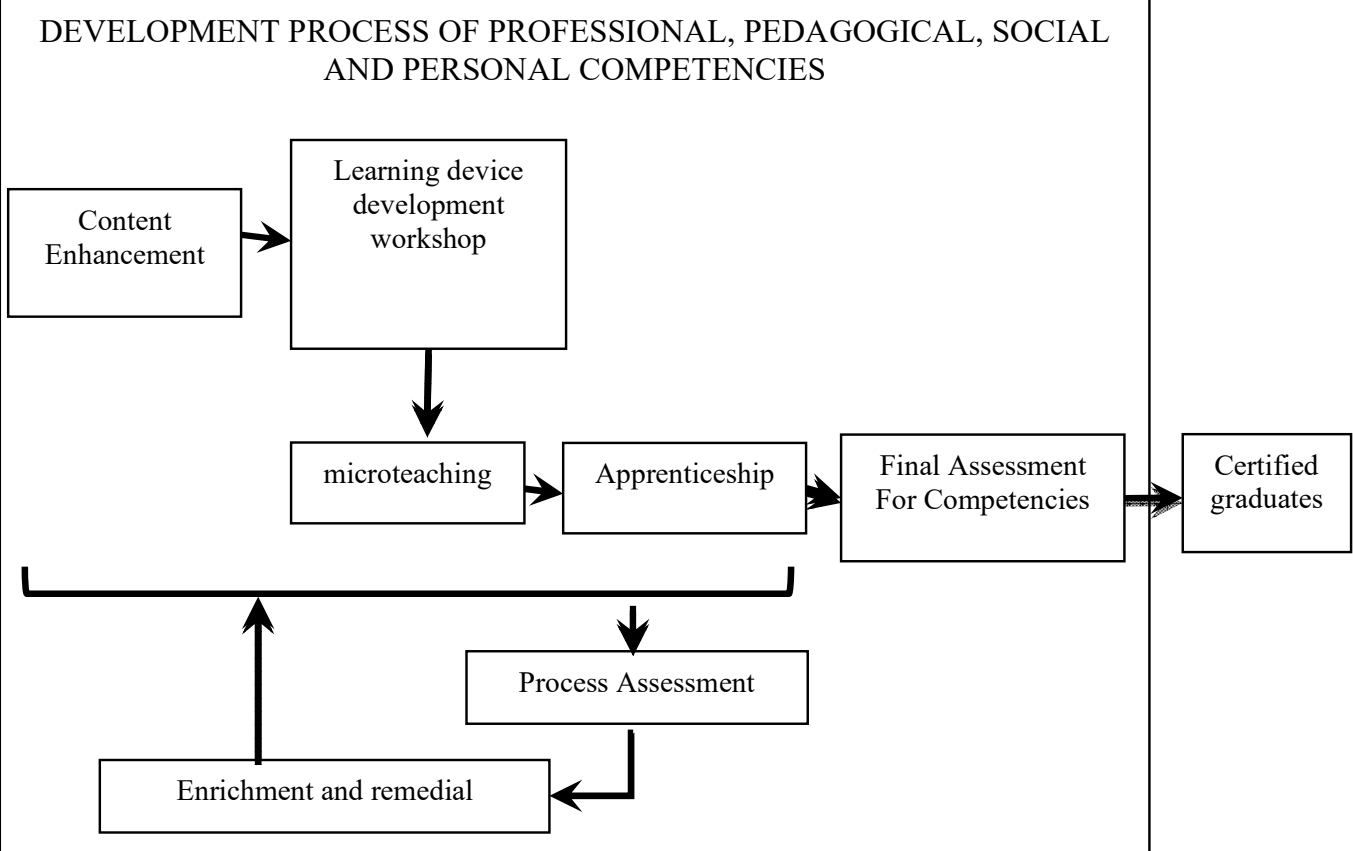

Figure 5. Process of PPG Program

Assessment of the process and learning outcomes of students participating in the PPG program include: process and final assessment. The assessment process is intended to measure the development of program participants related to competence, development of learning tools and apprenticeship processes. As students participating in the program whose development is still considered unsatisfactory will be given enrichment and remediation to ensure the achievement of the set standards. Meanwhile, the final assessment is done through a written test and a performance test in accordance with national standards of teacher competence. Performance test is done by assessing the performance of students participating in the program in carrying out teaching in the classroom. While the written competency test is conducted by the national committee. Participants who pass the assessment of the process and product development of learning tools, PPL processes and products, as well as competency tests obtain educator certificates that apply nationally.

\section{Conclusion}

Based on the description above, revisions that are deemed necessary to do with the previous PPG program include:

1. Input

a. The selection process that takes into account the personality, interests and talents as well as the actual and potential abilities of prospective PPG program participants.

b. Emphasis on personality, interests and talents needs to be considered so that it is expected to be obtained by teachers who truly have dedication to the task of educating.

2. Process

a. The whole process of the PPG program is intended for the integrated development of professional, pedagogical, social and personality competencies

b. Learning outcomes, graduate competency standards, content standards should reflect level 7 (seven) qualifications from the Indonesian National Qualification Framework (KKNI)

c. The standard program implementation process meets the educational characteristics of the PPG program as regulated by applicable regulations

d. Evaluation of the process and enrichment and remediation activities have an important role in ensuring the achievement of the competence of professional teachers as stipulated in the National Education Standards, so this stage needs more attention.

\section{References}

Dick, W., Carey, L., \& Carey, J.O. (2015), “The systematic design of instruction ( $8^{\text {th }}$ edition)", Upper Saddle River: Pearson.

Gall, M.D., Gall, J.P., \& Borg, W.R. (2003), “Educational research: An indtroduction (7 $7^{\text {th }}$ ed.)”. Boston: Allyn and Bacon. 
Nurlaela, L. (2018). Tugas Berat Pendidikan Profesi Guru. http://ppg.ristekdikti.go.id/ tugas-berat-pendidikanprofesi-guru/. Accessed on $27^{\text {th }}$ of May 2019.

Indonesian Government Regulation number 19 of year 2017 about Revision of Indonesian Government Regulation number 74 of year 2008 about Teacher.

Ministry of Research, Technology and Higher Educational Regulation number 55 of year 2017 about Teacher Education Standard.

Indonesian Act number 14 of year 2005 about Teacher and Lecturers. 